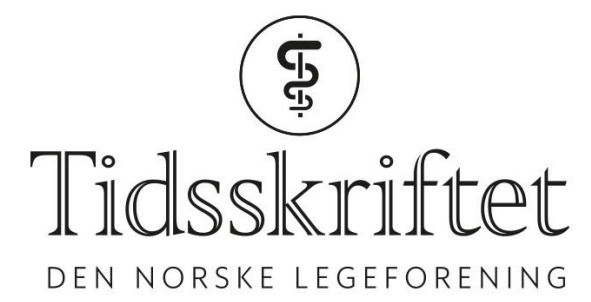

\title{
Antipsykotika i mer enn 2 år?
}

KOMMENTAR

\section{J $\varnothing R G E N$ G. BRAMNESS}

E-post: j.g.bramness@medisin.uio.no

Jørgen G. Bramness er seniorforsker ved Nasjonal kompetansetjeneste for samtidig rusmisbruk og psykisk lidelse (N-ROP) og professor II, Institutt for klinisk medisin, Det helsevitenskapelige fakultet, Universitetet i Troms $\emptyset$ - Norges arktiske universitet.

Ingen oppgitte interessekonflikter.

\section{JAN IVAR RØSSBERG}

Jan Ivar Røssberg er professor ved Universitetet i Oslo Ingen oppgitte interessekonflikter.

Geir Smedslund og Camilla Stoltenberg skriver i en debattartikkel i Tidsskriftet om en kunnskapsoppsummering (1) fra Folkehelseinstituttet om effekt og bivirkninger ved langtidsbehandling med antipsykotika (2). De konkluderte med at mortaliteten etter bruk av antipsykotika i mer enn to år var litt lavere, men at pasienter uten antipsykotika fungerte bedre arbeidsmessig. Resultatene for reinnleggelser og bivirkninger var det vanskeligere å tolke. Årsakssammenhenger kunne ikke fastslås.

Smedslund og Stoltenberg hevder at det siden antipsykotika ble tatt i bruk for ca. 60 år siden ikke er utført en eneste placebokontrollert studie på disse legemidlene. Vi går ut fra at dette er en skrivefeil, da det er utført svært mange slike undersøkelser som viser de positive resultatene av legemidlene $(3,4)$. Referansen de bruker skriver riktignok at slike studier ikke er gjort i de senere årene fordi det ville være uetisk og umulig (5), men studien konkluderer med, og det er viktig i denne sammenheng, at det er lite støtte for negative langtidseffekter av antipsykotika.

Er det riktig å avvise effekten av et medikament etter 2 år når man vet at det er effektivt i 2 år, slik Smedslund og Stoltenberg så å si gjør? For mange av våre legemidler er det ikke gjort randomiserte kontrollerte fors $\emptyset \mathrm{k}$ over så lang tid, men det er jo ikke det samme som at medikamentene ikke virker etter 2 år.

Har Smedslund og Stoltenberg noen hypoteser om hvorfor antipsykotika eventuelt skulle slutte å virke etter en viss tid? I så fall burde de ha kommet med slike teoretiske betraktninger i sitt innlegg. På bakgrunn av en liten debattartikkel (6) anfører de at hyppigere tilbakefall ved seponering av antipsykotika kan skyldes hypersensitiviseringssyndromet (abstinens). Smedslund og Stoltenberg ville ved nærmere undersøkelser funnet at dette har lite støtte i nyere empirisk litteratur $(7,8)$.

Er det nødvendig med placebokontrollerte undersøkelser for å kunne trekke konklusjoner? Forfatterne etterlyser gode helseregistre, og det skal vi ikke argumentere mot. Det er likevel interessant at de først i innlegget skriver at observasjonsstudier, basert på registre, har så 
mange systematiske skjevheter at de har lite troverdighet, mens de på slutten argumenterer for at vi må ha bedre slike registre. Selv om de etterlyser bedre studier fra bedre registre blir det litt paradoksalt å bruke denne rapporten som i liten grad bruker observasjonsstudier (1), til å argumentere for helseregistre til å gjennomføre nettopp observasjonsstudier.

Bruk av antipsykotiske legemidler er én viktig grunnpilar i behandlingen av alvorlige psykiske lidelser. Selvsagt ikke alltid, til alle eller hele tiden. Vi må ta i bruk all kunnskapen vi kjenner til når vi skal gi råd til pasientene. Da må vi basere oss på en rett tolkning av den beste eksisterende kunnskap, noe vi synes både kunnskapsoppsummeringen (1) og kommentaren i tidsskriftet (3) kommer til kort i forhold til.

\section{LITTERATUR:}

1. Smedslund G, Siqveland J, Kirkehei I et al. Langtidsbehandling med antipsykotika hos personer med schizofrenispektrumlidelser: en systematisk oversikt. Oslo: Folkehelseinstituttet, 2018.

2. Smedslund G, Stoltenberg C. Hva vet vi om langtidsvirkninger av antipsykotika? Tidsskr Nor Legeforen 2018; 138: doi:10.4045/tidsskr.18.0729. [PubMed][CrossRef]

3. Leucht S, Cipriani A, Spineli L et al. Comparative efficacy and tolerability of 15 antipsychotic drugs in schizophrenia: a multiple-treatments meta-analysis. Lancet 2013; 382: 951 - 62. [PubMed][CrossRef]

4. Zhu Y, Li C, Huhn M et al. How well do patients with a first episode of schizophrenia respond to antipsychotics: A systematic review and meta-analysis. Eur Neuropsychopharmacol 2017; 27: 835 - 44 . [PubMed][CrossRef]

5. Goff DC, Falkai P, Fleischhacker WW et al. The Long-Term Effects of Antipsychotic Medication on Clinical Course in Schizophrenia. Am J Psychiatry 2017; 174: 840 - 9. [PubMed][CrossRef]

6. Gøtzsche PC, Young AH, Crace J. Does long term use of psychiatric drugs cause more harm than good? BMJ 2015; 350: h2435. [PubMed][CrossRef]

7. Emsley R, Nuamah I, Gopal S et al. Relapse After Antipsychotic Discontinuation in Schizophrenia as a Withdrawal Phenomenon vs Illness Recurrence: A Post Hoc Analysis of a Randomized PlaceboControlled Study. J Clin Psychiatry 2018; 79: 4. [PubMed][CrossRef]

8. Taylor MJ, Yim S. Is there rebound psychosis on withdrawal of antipsychotic medication in schizophrenia? Schizophr Res 2018; Sog20-9964(18)30341-4 akseptert for publisering. [PubMed]

Publisert: 26. november 2018. Tidsskr Nor Legeforen. DOI:10.4045/tidsskr.18.o844

(C) Tidsskrift for Den norske legeforening 2020. Lastet ned fra tidsskriftet.no 